\title{
Expression of VEGF and CD68 in the Placenta of Gestational Diabetic Mothers (Immunohistochemistry and Ultrastructural Study)
}

\author{
Expresión de VEGF y CD68 en la Placenta de Madres Diabéticas \\ Gestacionales (Estudio Inmunohistoquímico y Ultraestructural)
}

Yavuz, D.*; Balsak, D."; Ekinci, C.**; Tahaoglu, A. E.**; Togrul, C."; Görük, N.**; Aktas, A.** \& Karaman, E.**

YAVUZ, D.; BALSAK, D.; EKINCI, C.; TAHAOGLU,A. E; TOGRUL, C.; GÖRÜK, N.; AKTAS, A. \& KARAMAN, E. Expression of VEGF and CD68 in the placenta of gestational diabetic mothers (Immunohistochemistry and ultrastructural study). Int. J. Morphol., 33(2):522-526, 2015.

SUMMARY: Placental angiogenesis, is essential for embryonic and fetal development. In this study, 18 gestational diabetes mellitus and 22 control pregnancies were included. Gestational diabetes mellitus (GDM) groups compared to the control group significantly higher values were detected $(\mathrm{p}<0.01)$. The following histological results were assessed; villous immaturity, chorangiosis, presence of, sncytial knots,mononuclear cell infiltration ischemia and fibrinoid necrosis. To evaluate and compare the placental histology of normal and GDM pregnancies. placentas of pregnant women with gestational diabetes also in terms of angiogenesis and macrophages and ultratructural revealed by examining the possible relationship between fetal complications were investigated.

KEY WORDS: Gestational Diabetes (GDM); VEGF; CD68; Ultrastructure.

\section{INTRODUCTION}

Placental functions, which are essential for growth and development of the fetus, include gaseous exchange, provision of nutrients, hormonal excretion and transmission of maternal antibodies (Sadlier, 2000; Higgins \& Mc Auliffe, 2010). Gestational diabetes mellitus (GDM) is associated with numerous complications including macrosomia, neonatal metabolic disorders, respiratory distress syndrome and newborn death. Additionally, GDM poses an increased risk for development of type 2 diabetes mellitus later in life for both child and mother (Barnes-Powell, 2007). Insufficient placental trophoblast invasion in bed, decreased perfusion that increased lipid peroxidation and causes accumulation of oxygen free radicals. This case the activation of neutrophils and macrophages, endothelial cell activation and then causes an increase in the production of cytokines. Endothelial damage in the vessel wall leads to the accumulation of platelets and fibrinogen. The placenta contains numerous macrophages, both in the decidua and the chorion villous stroma. Hofbauer cells (HCs) express classic monocyte/macrophage markers, such as CD68 and are assumed to be placental macrophages located in the chorionic villous stroma (Joerink et al., 2011). These cells can be found within the placental villi from week four of pregnancy until term and are localized near both fetal vessels and trophoblasts (Anteby et al., 2005).

The purpose of this study, gestational diabetic mothers placenta, endothelial cells and macrophages, immunohistochemical and ultrastructural changes that may have occurred to investigate.

\section{MATERIAL AND METHOD}

Placental tissue was obtained from the maternity hospital. In our study, two groups were formed consisting of 40 pregnant patients. Pregnant women diagnosed with GDM $(n=18)$ in the GDM group, remaining below the threshold values of pregnant women $(n=22)$ were used as the control group. Following a $12 \mathrm{~h}$ overnight fast, 08:00 and 10:30 from patients, venous blood samples were taken after 15 minutes. Gestational diabetes mellitus was diagnosed by $50 \mathrm{~g}$ OGTT venous plasma / serum threshold

\footnotetext{
* Department of Obstetrics and Gynecology, Diyarbak Maternity and Children Hospital, Diyarbakir, Turkey.

** Department of Histology and Embryology, School of Medicine, Dicle University, Diyarbakır, Turkey.
} 
values as follows: $50 \mathrm{~g}$ OGTT $<140 \mathrm{mg} / \mathrm{dL}$ is normal. 50 g OGTT 140-200 mg / dL is a 3-hour $100 \mathrm{~g}$ OGTT. $50 \mathrm{~g}$ OGTT $\geq 200 \mathrm{mg} / \mathrm{dL}$ in patients directly GDM is diagnosed and treatment begins fasting blood glucose $\geq 140 \mathrm{mg} / \mathrm{dL}$ are considered in this case diabetes fasting blood glucose $\geq 140 \mathrm{mg} / \mathrm{dL}$ are considered in this case diabetes. Immediately after delivery, the placental tissue was transported from the delivery room to the laboratory. After preliminary gross examination, tissue samples were obtained from the fetal side of the placenta. The specimens were immersed in $10 \%$ buffered formaldehyde. Four mm sections were cut and made into slides. These were processed forhematoxylin-eosin and Trichrom Masson staining, carried out according to conventional procedures.

Immunohistochemical Technique. Formaldehyde-fixed tissue was embedded in paraffin wax for further immunohistochemical examination. Sections were deparaffinized in absolute alcohol. Endogenous peroxidase activity was blocked with absolute methanol containing $0.4 \%$ hydrochloric acid $(1 \mathrm{M})$ and $0.5 \%$ hydrogen peroxide $(100$ volumes) for $40 \mathrm{~min}$ at room temperature. After washing in water followed by $0.05 \mathrm{M}$ Tris-buffered saline, the sections were incubated in $1 \%$ trypsin. After washing in cold water, staining was carried out as above, using Ki67 (clone MIB1, Dako, 1/100) and CD68 as primary antibodies.
Electron Microscopy technique. The pieces of tissue were immediately placed in $2.5 \%$ glutaraldehyde, buffered for 4 $\mathrm{h}$, then fixed in $\mathrm{OsO} 4$ for $2 \mathrm{~h}$, dehydrared in graded ethanols, and embeded in araldite. Semithin sections of $1 \mathrm{~mm}$ thick were cut and stained with methylene blue-azure II for light microscopic examination Thin sections of $70 \mathrm{~nm}$ thick were stained with lead citrate-uranyl acetate and examined and photographed under Zeiss Electron microscope 900S.

\section{RESULTS}

Morphologically, the placenta of gestational women is characterized by an increase in the number of terminal villi and capillaries, presumably as part of a compensatory mechanism to maintain homeostasis at the maternal-fetal interface. Placental histology showing ischaemic villi with increased syncytial sprouts and fibrin and cellular villi with increased syncytial sprouts and villous fibrin deposition. Another common abnormality found in villous of diabetic placenta is villous edema. Villous stromal fibrosis was significantly increased. Perfusion is impaired stromal fibrosis of the villi and causes the formation of excessive syncytial nodes. Morphological analysis revealed collagen deposition around large arteries in all groups.

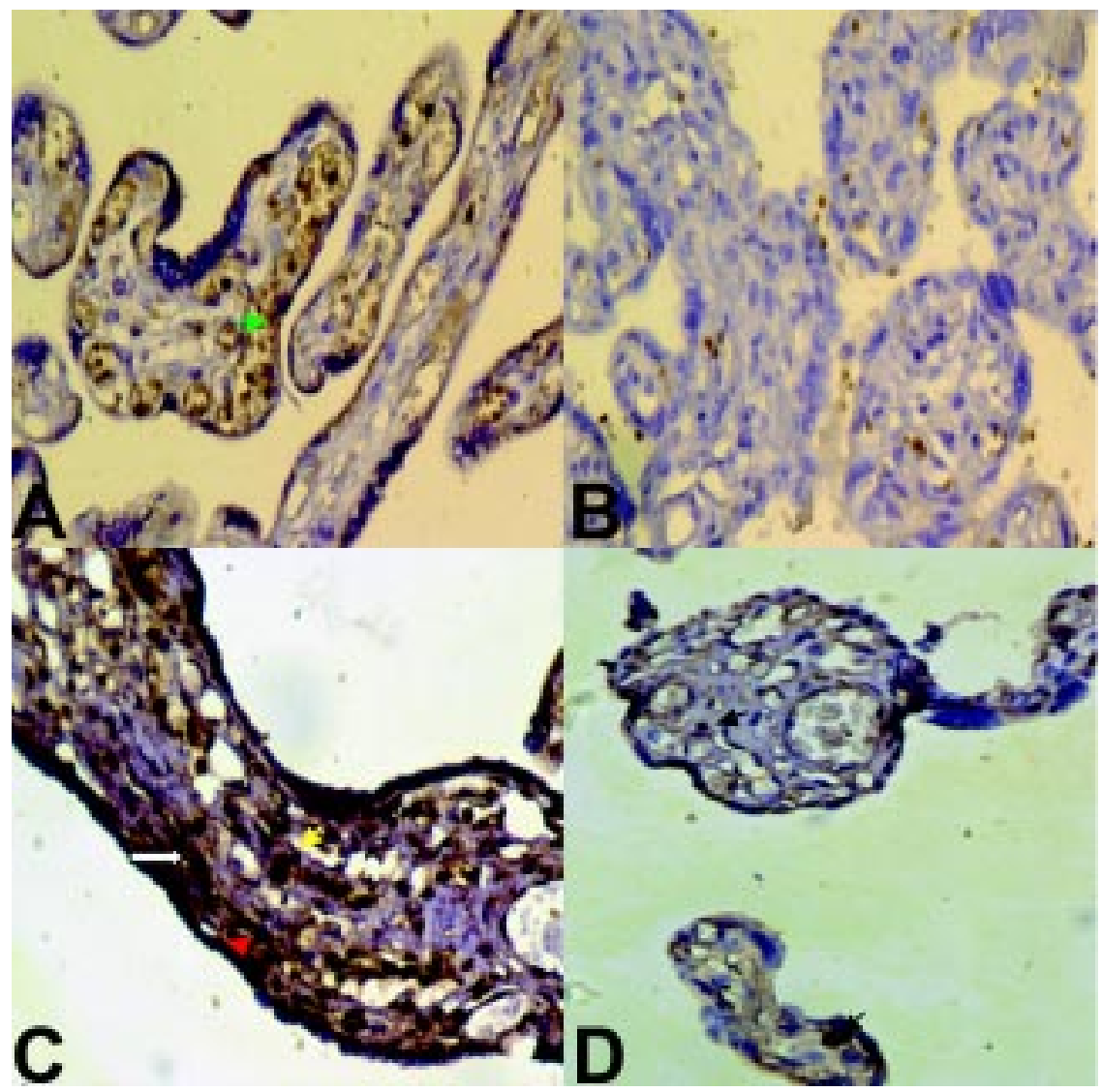

Fig. 1. A Cytotrophoblast cells close to blood vessels, an increase in the expression of VEGF (arrow), (VEGF immunostaning, Bar $50 \mu \mathrm{m}) \mathrm{B}$. VEGF expression weak in non diabetic villi (VEGF immunostaning, Bar $50 \mu \mathrm{m})$. C. Trophoblast cells close to blood vessels near the Hofbauer cells CD68 reaction positive, also CD68 expression positive (arrow) Stromal inflamatuar cells (arrow) (CD68 immunostaning, Bar 100 $\mu \mathrm{m})$, D. Hofbauer cells expression in in Non diabetic chronon vill (CD68 immunostaning Bar $50 \mu \mathrm{m}$ ). 

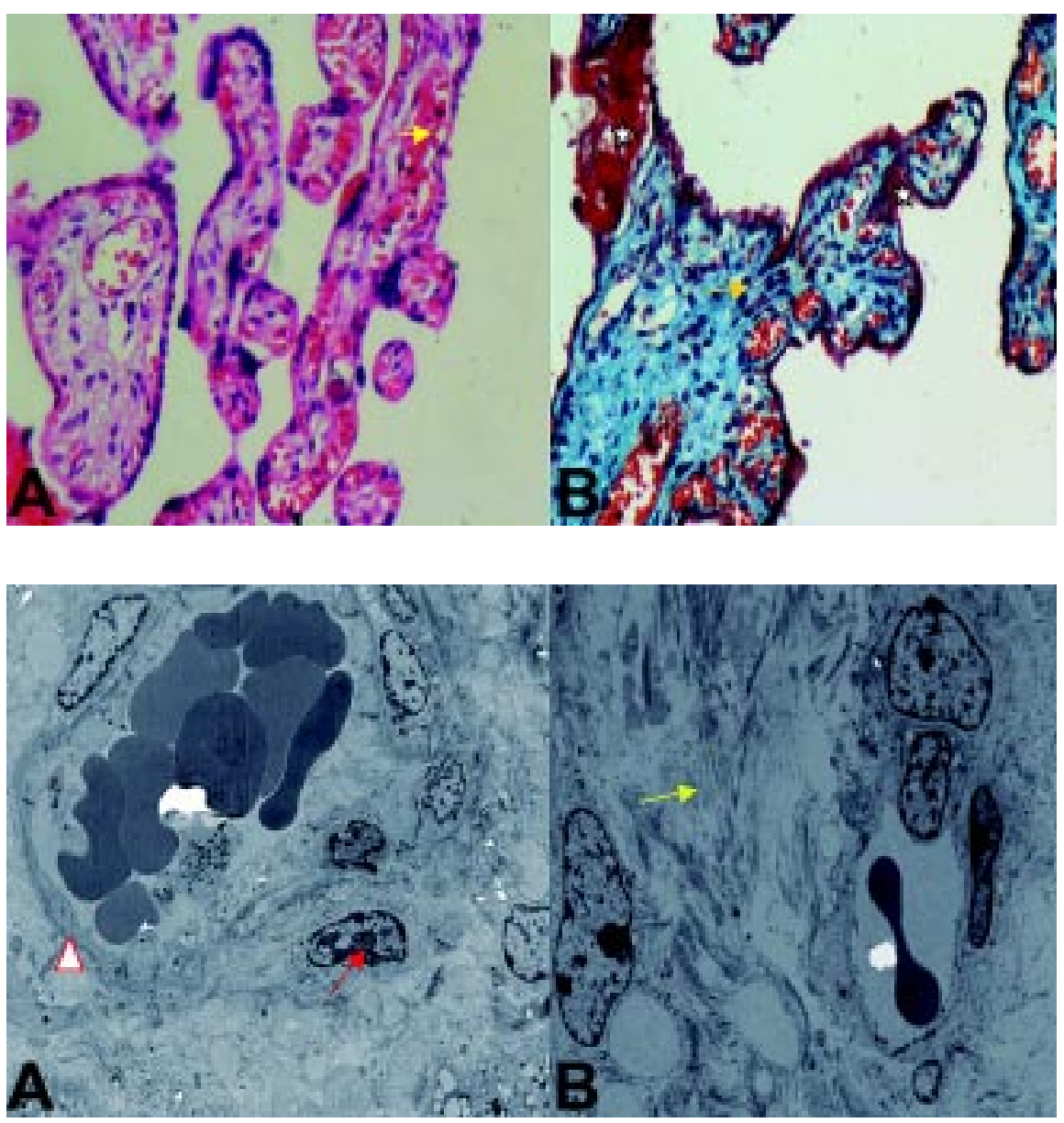

Fig. 2. A. Hemorrhage and dilatation in blood vessel, increase of syncial knots (arrow) (H-E, Bar $50 \mu \mathrm{m})$, B. A increase Stromal fibrrosis (arrow), syncytial sprouts and villous fibrin deposition (star) (TrichromMasson, Bar $50 \mu \mathrm{m})$.
The expression of VEGF and its receptors was ascertained to be increased in the placental chronic villi, mostly in gestational diabetes. Diabetic placenta group; chorionic villi, in trophoblastic cells in the blood vessels close to the prominent VEGF expression was observed (Fig. 1A). VEGF weak expression was observed in Non diabetic villi (Fig. 1B). In all placental tissues of gestasyonel diabetes group, immunohistochemical staining demonstrated the presence of CD-68.

Trophoblast and hofbauer cells were stained with CD68. Hofbauer cells were generally observed in close vicinity to the vascular area in the villous stroma also around the vein CD68 expression was observed also in inflammatory cells (Fig. 1C).

Hofbauer cells expanded in the endoplasmic reticulum, swollen mitochondria and the nucleus was observed in the form of heterochromatin. There was focal increase in thickness of the endothelial basement membrane was seen in the majority of placentas. We observed a general increase in collagen component of villous stroma.

\section{DISCUSSION}

Fig. 3. A. Thickness of the endothelial basement membrane (arrow), Hofbauer cell nucleus in the form of heterochromatin (arrow) B. A increase in collagen fibers of villous stroma.

Diabetic insult at later stages of gestation, such as may occur in gestational diabetes, will foremost lead to shortterm changes in a variety of molecules for key functions including gene expression (Mayhew, 2002).

Morphological analysis of placentas from women with mild hyperglycemia has revealed an increase in the number of villi and vessels. Both fibrinoid necrosis and villous immaturity can also affect oxygen exchange (Campbell et al., 2009). Histopathology revealed chorioamnionitis, villous dysmaturity, retroplacental hemorrhage, patchy villitis, fibrin encasement of villi. Gestational diabetes mellitus one of these histopathology, in which its associated metabolic derangements will alter feto-placental endothelial activities in normal placentas, together with villous maturation, the barrier between maternal and fetal circulation is reduced by the thinning of the syncytiotrophoblast, reduction of cytotrophoblast, decreased mean villous (Tewari et al., 20011). Histologically, term 
placenta shows a large number of villi and syncytial knots. In these knots syncytiotrophoblast nuclei are arranged in clusters leaving thin areas of cytoplasm between them (Tewari et al.). Some authors of diabetes endothelial cell dysfunction caused by a decrease in the number of cells and expressed (Waltenberger, 2001; Loomans et al., 2004; Fadini et al., 2005). In our study, gestational diabetes group due to accumulation of amyloid in the area of stromal collagen fibers increase in villi are developed. In this vessels were found to change in the structure of the elastic structure (Figs. $2 \mathrm{~B}$ and $3 \mathrm{~B}$ ). Also in this group, vascular dilatation, basement membrane thickness is illustrated by dysfunction of endothelial cells (Figs. 2A and 3A).

Vascular endothelial growth factor (VEGF), human placenta is a glycoprotein found in glycosylated (Pietro et $a l ., 2010)$. In the placenta of women with gestational diabetes, there is a significant decrease in reactivity of VEGF, detected only in the trophoblast. Diabetic placenta group; chorionic villi, in trophoblastic cells in the blood vessels close to the prominent VEGF expression was observed (Fig. 2A). Vasculogenesis and vascular permeability is important for control. MHC class I-II antigens and various interleukins are produced in Hofbauer cells, and these may play a role in immunological reactions within the placental villi. These cells may participate in placental inflammation or fetal immunological mechanisms, such as tolerance and fetal protection (Wetzka et al., 1997). In this study, we noted a decrease in the number of vascular endothelial cells and cell hyperplasia. However, considered to be the causes of diabetes, affecting angiogenesis. The absorption of immune complexes, antigen presenting function, and stromal fluid balance of the placenta have been attributed to Hofbauer cells (Anteby et al.). Guilbert et al. (1993) reported that Hofbauer cells are involved in vasculogenesis and angiogenesis of the placenta.

In this study, we studied the protein expression and distribution of VEGF and CD68 in placentas from hyperglycemic women; the results were compared with those of placentas from women with normal glycemia and gestational diabetes. Hofbauer cell and trophoblast cells show several similarities including characteristics used for identifying cell types like phagocytosis, non-specific esterase activity and expression of Fc receptors (Seval et al., 2007). In the present study, both Hofbauer cells and trophoblasts are immunostained with CD-68 Also around the vein CD68 expression was observed also in inflammatory cells.

\section{CONCLUSIONS}

These changes in gestational diabetes during pregnancy are associated with the increase in glucose dysfunction and inflammation in the blood vessels and blood flow because of increased fetal has developed a mechanism negatively.

YAVUZ, D.; BALSAK, D.; EKI'NCI' , C.; TAHAOGLU, A. E; TOGRUL, C.; GÖRÜK, N.; AKTAS, A. \& KARAMAN, E. Expresión de VEGF y CD68 en la placenta de madres diabéticas gestacionales (estudio inmunohistoquímico y ultraestructural). Int. J. Morphol., 33(2):522-526, 2015.

RESUMEN: La angiogénesis de la placenta es esencial para el desarrollo embrionario y fetal. En este estudio, se incluyeron 18 casos de diabetes mellitus gestacional (DMG) y 22 embarazos de control. En grupos los de DMG en comparación con el control, se detectaron valores significativamente mayores $(\mathrm{p}<0,01)$ en los siguientes parámetros histológicos que fueron evaluados: inmadurez vellosa, chorangiosis, presencia de nodos sincicial, infiltración celular isquémica mononuclear y necrosis fibrinoide. La investigación de las placentas de mujeres con DMG, reveló mediante el examen en términos de angiogénesis, macrófagos y ultraestructural, la posible relación entre las complicaciones fetales.

PALABRAS CLAVE: Diabetes gestacional (DMG); VEGF; CD68; Ultraestructura.

\section{REFERENCES}

Anteby, E. Y.; Natanson-Yaron, S.; Greenfield, C.; Goldman-Wohl, D.; Haimov-Kochman, R.; Holzer, H. \& Yagel, S. Human placental Hofbauer cells express sprouty proteins: a possible modulating mechanism of villous branching. Placenta, 26(6):476-83, 2005.
Barnes-Powell, L. L. Infants of diabetic mothers: the effects of hyperglycemia on the fetus and neonate. Neonatal Netw., 26(5):283-90, 2007.

Campbell, I. W.; Duncan, C.; Urquhart, R. \& Evans, M. Placental 
dysfunction and stillbirth in gestational diabetes mellitus. $B r$. J. Diabetes Vasc. Dis., 9(1):38-40, 2009.

Fadini, G. P.; Miorin, M.; Facco, M.; Bonamico, S.; Baesso, I.; Grego, F.; Menegolo, M.; de Kreutzenberg, S. V.; Tiengo, A.; Agostini, C. \& Avogaro, A. Circulating endothelial progenitor cells are reduced in peripheral vascular complications of type 2 diabetes mellitus. J. Am. Coll. Cardiol., 45(9):1449$57,2005$.

Guilbert, L.; Robertson, S. A. \& Wegmann, T. G. The trophoblast as an integral component of a macrophage-cytokine network. Immunol. Cell. Biol., 71(Pt. 1):49-57, 1993.

Higgins, M. \& Mc Auliffe, F. A review of maternal and fetal growth factors in diabetic pregnancy. Curr. Diabetes Rev., 6(2):116-25, 2010.

Joerink, M.; Rindsjö, E.; van Riel, B.; Alm, J. \& Papadogiannakis, N. Placental macrophage (Hofbauer cell) polarization is independent of maternal allergen-sensitization and presence of chorioamnionitis. Placenta, 32(5):380-5, 2011.

Loomans, C. J.; de Koning, E. J.; Staal, F. J.; Rookmaaker, M. B.; Verseyden, C.; de Boer, H. C.; Verhaar, M. C.; Braam, B.; Rabelink, T. J. \& van Zonneveld, A. J. Endothelial progenitor cell dysfunction: a novel concept in the pathogenesis of vascular complications of type 1 diabetes. Diabetes, 53(1):195-9, 2004.

Mayhew, T. M. Fetoplacental angiogenesis during gestation is biphasic, longitudinal and occurs by proliferation and remodelling of vascular endothelial cells. Placenta, 23(10):742-50, 2002.

Pietroa, L.; Daher, S.; Rudge, M. V.; Calderon, I. M.; Damasceno, D. C.; Sinzato, Y. K.; Bandeira, C. \& Bevilacqua, E. Vascular endothelial growth factor (VEGF) and VEGF-receptor expression in placenta of hyperglycemic pregnant women. Placenta, 31(9):770-80, 2010.

Sadlier, T. W. Fetal membranes and placenta. In: Sadlier, T. W. (Ed.). Langman's medical embryology. Baltimore, Lippincott Williams and Wilkins, 2000. pp.136-57.

Seval, Y.; Korgun, E. T. \& Demir, R. Hofbauer cells in early human placenta: possible implications in vasculogenesis and angiogenesis. Placenta, 28(8-9):841-5, 2007.

Tewari, V.; Tewari, A. \& Bhardwaj, N. Histological and histochemical changes in placenta of diabetic pregnant females and its comparision with normal placenta. Asian Pac. J. Trop. Dis., 1(1):1-4, 2011.

Waltenberger, J. Impaired collateral vessel development in diabetes: potential cellular mechanisms and therapeutic implications. Cardiovasc. Res., 49(3):554-60, 2001.
Wetzka, B.; Clark, D. E.; Charnock-Jones, D. S.; Zahradnik, H. P. \& Smith, S. K. Isolation of macrophages (Hofbauer cells) from human term placenta and their prostaglandin E2 and thromboxane production. Hum. Reprod., 12(4):847-52, 1997.

\author{
Correspondence to: \\ Deniz Balzak \\ Department of Obstetrics and Gynecology \\ Faculty of Medicine \\ University of Halic \\ TURKEY
}

Email: denizbeyram@gmail.com

Received: 24-11-2014

Accepted: 17-03-2015 